\title{
Engaging the work of Professor Christina Landman
}

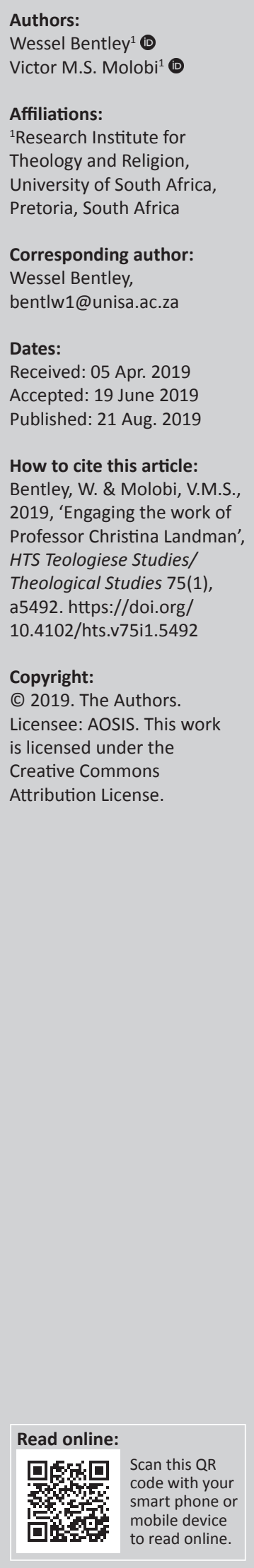

Professor Christina Landman is a groundbreaking academic who seeks to give a voice to the marginalised. This article, which serves as a contribution to her Festschrift, explores her research on women in church and society as reflected in her publications over the last decade. Landman argues that although much has been done to advance equality for women in society, women in general still feel the effects of historical one word identities as espoused by colonial theology. In addition, she argues that women have experienced marginalisation in church, culture and society at large. This article explores her research methodology, gives an overview of her research findings and concludes with a note on healing.

Keywords: Christina Landman; Festschrift; Women; Theology; Research; South Africa.

\section{Introduction}

Professor Christina Landman has been in academia for most of her life. For the last 23 years, she has worked at the Research Institute for Theology and Religion, where the authors of this article are her colleagues. Prior to this, she was a scholar in the Department of Church History at the University of South Africa. She is not only an academic, but she is also much more; she is an ordained minister, an activist, a counsellor, a church leader and a mother. Roles do not define her. They can neither confine her. She is Christina Landman, the creator of avenues, the shaker of seemingly immovable foundations and the one who dares to break through the walls of oppression, marginalisation and structural disempowerment.

This Festschrift is a small token of appreciation for this esteemed colleague's contribution not only to academia, but also to the communities with whom she has engaged over the years. If an iconic person were to be identified in South African academic theology, it is without a doubt that Christina Landman would certainly be named. We take it for granted that both women and men form part of the academic community; it is only when one reads in her curriculum vitae ${ }^{1}$ that she was the first South African born woman to become a professor in theology at a South African university, that one realises how recent the institutional subjugation of women was still in effect, and what odds Landman had to overcome in order to pave the way for other women to be accepted as equals in the academic workplace. Of course it can be argued that in academia and society at large, we still struggle against patriarchy and the marginalisation of women, but we have an idea that we would have been in a much worse position had Christina Landman been silent. These introductory words are clumsy; we write these as men aware that our gender bias cannot succinctly and adequately celebrate Christina's life and contribution, but we hope that these words are received as a heartfelt celebration.

Christina Landman's career boasts what most academics can only dream of. Her work includes over 65 academic articles published in accredited peer-reviewed journals, numerous academic and popular monographs, chapters in books and articles in popular publications. She holds a C2 rating with the National Research Foundation, acknowledging that her work is recognised both locally and internationally. Her name is synonymous with theological work done among those who find themselves on the margins of society, providing a voice for those who are either ignored, shunned or rendered voiceless. She gives them a voice by 'deconstructing dominant public discourses in church and society' (Plaatjies Van Huffel 2014:69). Among these voices, we find those of youth (see Landman 2015), women in rural areas and people in correctional facilities. This article celebrates the work of Christina Landman by engaging her published work of the last 10 years, specifically that focusing on women in society. For a further reading of her work, we refer the reader to Mary-Anne Plaatjies van Huffel's article, which gives a thorough overview of Landman's life and work (Plaatjies Van Huffel 2014).

1.To access Landman's curriculum vitae, see http://www.christina-landman.co.za/cv.htm.

Note: Christina Landman Festschrift, sub-edited by Wessel Bentley (University of South Africa) and Victor S. Molobi (University of South Africa). 


\section{Employing a helpful research methodology}

Christina Landman prefers to conduct her research at the coalface; she immerses herself in the context of the people with whom she engages. She hereby avoids the trap that so many academics fall into, namely, to conduct research from afar, from the safety of their offices and desks. Research needs conversation, to be able to see the person face to face. Doing engaging research with people by means of structured interviews can still be a very segregating act; the researcher can be a detached observer, while the person interviewed is nothing more than an object of study and observation. Landman does not go down this route, but describes the form of narrative enquiry she employs in detail in her publication Youth on the margins as agents of change? The call for the opening of mines in Dullstroom-Emnotweni based on the Freedom Charter (1955) (Landman 2015:157-158). Here she describes the values of this form of narrative inquiry (as first put forward by Pinnegar \& Danyes in Clandinin 2007), as to remove the distinction between researcher and those researched ... that everyone has a story to tell ... that there is no differentiation between the researcher and the researched, but that everyone becomes coresearchers in the project ... that the researcher draws alongside the coresearchers (Landman \& Yates 2018; Swartz 2011) being aware of their context and non-verbal cues ... to refrain from interpreting their narrative, but to represent their voices unmediated.

By employing this research methodology, Landman is breaking boundaries by challenging traditionally accepted methodologies that rely on the distance created in Western positivism. Landman defends this methodological position by citing Prof. Rothney Tshaka, who argues that such a methodology is more true to the values held in the African context regarding how research should be done (Tshaka 2016) compared to the values of traditional Western methodologies. So, Landman speaks and is enabling the marginalised to speak by unlocking their voices by means of conversation, co-research and codiscovery (Landman \& Yates 2017).

This methodology is indeed true to our African context, where communality is not only emphasised, but also pivotal in any human interaction. The only question one can raise is whether it is truly possible to represent another person or community's voice 'unmediated'. By virtue of being on the 'listening end' of the interviews (or conversations), the processes of receiving and processing information necessitates a measure of interpretation on behalf of the researcher.

The interpretation and relaying of information are thus tainted by the interviewer's own paradigms, worldview and moral framework (see Kelly 2006:349-352). It is, however, interesting to see how Landman reflects the views of her coresearchers in her findings. In her articles, Landman starts by setting the scene for the research question. The reader is exposed to the historical journey that the research question has undergone, followed by immersing the reader into the context in which the coresearchers find themselves.
She then simply retells the coresearchers' stories, often leaving the reader so fascinated with their accounts that one almost forgets that the stories have something to do with the subtly posed research question. Her articles then conclude by highlighting parts of the narrative in light of the research question, allowing the reader to discover (alongside Landman and her coresearchers) the insights gained from the narrative.

Landman therefore does not seek to merely convince cognitively, but by employing empathy in conversation allows the reader to connect with the coresearchers (more so than only with the research itself), becoming empathic themselves by listening to the voices that would otherwise not be heard.

So, among many marginalised groups, Landman reflects the voices of women in church and society, and it would be incumbent on us as readers to hear what women have to say.

\section{What are women saying? An unhealthy religious history of identity}

One of the underlying themes in conversations with women across the cultural spectrum is the observation that women still feel that gender inequality is perpetuated in both church and society. Although the work of creating awareness of gender equality in society has come a long way, it appears that many women have internalised the roles assigned to them by patriarchal religious and social structures (Landman 2017:3).

In her controversial but groundbreaking book, The piety of Afrikaans women (1994), Landman already pointed out how Calvinist Christianity (primarily) in South Africa perpetuated sexism and gender inequalities in both church and society. She traces the socioreligious subjugation of women all the way back to the Orthodox Calvinism of Maria Quevellerius van Riebeeck, the wife of Dutch explorer, Jan van Riebeeck. The colonial-missional work of the early Calvinist settlers was characterised by it offering a colonising theology that emphasised the dynamics of sin-soul-salvation (Landman 2009:12). The strict focus on the human fallen state necessitated a gospel that required adherents to recognise their own brokenness, that their souls were fundamentally doomed to damnation and that they utterly depended on the salvific work of Christ for their redemption. Along with the guilt of sin, people, especially women, had to observe their respective positions at home, in society and the church, which reflected their need for and striving towards a state of salvation. Landman further argues that these early colonial women, and later their descendants, the Afrikaans women, wilfully subscribed to these values and passed them on to women of different cultures and races with whom they shared their faith (Landman 2017:3).

This is not to say that this was the only Christian narrative concerning women's expressions of religious piety. It is interesting that German women, with their Lutheran 
and Moravian roots, offered a theological counternarrative, which did not necessarily challenge the patriarchal structures in existence. In the description of piety of women in 1930-1990, Landman identifies differences between the Afrikaans (Calvinist) and German (Lutheran) outlooks on their role in religious life. The Calvinists proclaimed a theology where 'piety ... is, in the personal sphere, one of self-humiliation and self-hate' (Landman 2014:123), and 'brought up with the idea of predestination and that life is predestined to be suffered according to God's will' (Landman 2014:123). To the Lutheran women, Christian piety rather focused on the notion of duty in light of Christian faith and emphasised the notion of free will instead of predestination (Landman 2014:123). The woman's diminutive role and place was or is therefore either believed to be part of God's plan that needed to be accepted and endured to receive salvation, or part of women's duty that should be embraced and wilfully participated in. Neither of these theological positions adequately challenged the perpetuated perception that women occupied fewer positions or stations in church and society.

From a Christian socioreligious perspective it should therefore not come as a surprise that society at large and many (not all) women in particular often seem to have adopted an identity of women that is in a manner of speaking 'prescribed'. It is an identity that is the consequence of what for generations has been believed to be religio-socionormative, an image endorsed by culture, religion and society ${ }^{2}$. These maladaptive social schemas are hard to break as they are perceived to be passed down from external sources that carry authority and therefore are often accepted as truth. When this truth is internalised, 'they influence the social world in ways that make it consistent with the schema' (Baron, Byrne \& Branscombe 2005:44). ${ }^{3}$ This beckons the question: are there safe spaces for women where their humanity and dignity are upheld?

\section{Safe spaces?}

Do women have safe spaces? In her research, Landman comes to the conclusion that women generally do not feel that they have safe spaces, especially in society, culture or the church. One would think that with the church's role in protecting human dignity and equality, it would be the one place where women were received in the same spaces as their male counterparts. In Safe spaces for women in the church: the case of Dullstroom-Emnotweni (Landman 2013), Landman identifies a disconnect in the relationship between men and women in the context of the church. In this study, women generally expressed that their preferred space in church was to participate in worship, and not necessarily to take up positions of leadership. This was congruent with their

2.That is not to say that all women just submitted to the patriarchal structures of their time. In an article reflecting on interviews with Lindiwe Myeza Landman celebrates the. In an article reflecting on interviews with Lindiwe the bravery and achievements of black women during the struggle agains apartheid, by both facilitating healing to communities and challenging the politica status quo (Landman 2012a).

3.For more on the ways in which religious practices can be used to challenge maladaptive schemas see (Bentley 2017). perception of themselves at home, where they generally believed that women are considered to be good if they learn from men (Landman 2013:176). Although some women expressed a readiness to take on leadership roles in the church, they generally expressed that they may not feel confident in actually doing so (Landman 2013:178).

It was interesting that male participants in this study were generally more in favour of women participating in leadership activities in church, more so than the women themselves. Landman made the following assessment of the responses: ' $[I] \mathrm{t}$ seems that the men gave politically correct answers in affording women leadership roles, but in fact think that women are good leaders only when they lead according to their traditional roles' (Landman 2013:184).

There are, however, Christian denominations where women have taken up positions that were once reserved for men. Do women feel safe here? The Methodist Church of Southern Africa (MCSA) recently celebrated the 40th anniversary of the first woman to be ordained to the ministry of Word and Sacrament - one of the first denominations in South Africa to do so. The MCSA has already adopted polity, which stipulates that all leadership structures of the denomination must have the following representation: $40 \%$ men, $40 \%$ women and $20 \%$ young people (not that 'young people' is a gender classification, but that $20 \%$ of the leadership should be young people of either gender). Further legislation is currently being considered to ensure greater representation of women among the bishops, so much so (it is proposed) that Conference (the highest legal authority of this denomination) can overturn the election of a male bishop and instead commission a woman to this office.

Irrespective of the seemingly structural and institutional focus on promoting gender equality in this denomination, women (in this case female ministers) generally still do not feel that the church offers them a safe space. In an article that Landman wrote with Rev Donald Williams, female ministers in the MCSA retell their stories of how their gender counts against them (Williams \& Landman 2016). They often expressed that they were considered for nonviable stations, that their communities did not accept them in the same manner as their male counterparts and that their families suffered under the social pressures exerted on them (the female ministers) to prove themselves worthy of their calling.

This research raises an important question: Is it enough for Christian denominations to create safe spaces for women through polity? One can argue that the church has a duel responsibility. Firstly, it needs to make sure that its own structures and polity are aligned for gender equality. Secondly, and in concert with the first, churches need to work on social perceptions through the intentional engaging with society on the role and identity of women (in church, society and culture). If denominations only facilitate polity and structure, it may be perceived that the church 
offers safe spaces for women out of political correctness. Political correctness needs to go hand in hand with principled belief, which is the ambit of the church's second responsibility as mentioned above. It may be asked: What should the church do first? The answer is that both actions should be performed in tandem. The institution of polity may at times seem to precede the inner convictions of society, but in itself polity may become instrumental in changing social perceptions. Polity steers a denomination in a direction where what was at one time accepted as political correctness, gradually becomes the currently accepted norm - a slow shift of creating awareness through intentionality until the 'change' is not perceived as artificial, but accepted, intentional practice.

The greater point is that even while churches are sorting out their structures, polity and engaging with society, women are still perpetually traumatised by being subject to socially endorsed patriarchy, not being able to find safe spaces where they are free from constructed roles of subjugation. So, where and how do women find healing?

\section{Women and healing}

When speaking about healing in this sense, it does not only refer to the healing of physical ailments and conditions, but the holistic healing of the person. In an article titled Traumatised between culture and religion: Women's stories (Landman 2012b), Landman investigated the tension that women experience between the healing offered within their church contexts and the restrictions placed on them by their respective cultures (Landman 2012b:9). A similar study was later done in Nkhoma in Malawi (Landman 2019). In both these articles harrowing stories were shared of how women not only experienced trauma in the quest for seeking healing, but that their culture or religious convictions became hindrances in facilitating the holistic healing that they desired. In both these articles it became obvious that the healing offered by churches and the cultural delineations of women (on what is considered to be their well-being, their bodies, their sexuality ...) are often framed within patriarchal and masculine narratives.

The conclusions of these articles were of particular importance. Landman and her coresearchers came to the conclusion that in order for women to find healing, it does not necessitate the absolute dismissal of either culture or religion. It is actually possible for women to experience healing by incorporating healthy aspects of both religion and culture. Their healing is then not only theirs, but becomes a voice that challenges the maladaptive perceptions in religion, culture and society of who women are. Society, the church and culture find healing when women do.

\section{Conclusion}

Landman (2017:1) reflects on Boesak's exposition of Biblical images of women perpetuated by society. Boesak (2005) identifies the following images (as summarised in Landman 2017:1):

1. Women are worthy only in their usefulness to church and family without agency of their own.

2. A good woman is submissive on all levels, privately and publicly.

3. Women should sacrifice themselves to the mission of the church, without acknowledgment that they themselves are victims of patriarchy.

4. A good white woman is one that is loyal to the nation and to her husband, while black women are to reject their cultures.

5. Women's piety is restricted to dealing with their personal sins, while they are not to express their piety in public.

6. Women are forbidden by the Bible to participate in ordained religion.

These points may seem to be completely out of place in a society which in principle endorses human rights and gender equality and opposes all forms of violence and discrimination against women. Yet, these perceptions are rife in the actual practice of culture, religion and society. Landman shines a spotlight on this social, cultural and religious hypocrisy. Where the dominant voices speak with forked tongue, it is Landman's research that is giving volume to the voices of women who suffer under this hypocrisy. Her research does not pose an aggressive attack on what is considered to be normative, but through the emphatic sharing of stories she manages to lift the lived experiences of women for all to see, so that those who are confronted by these narratives are convicted of their sins and (hopefully) led to a place of repentance. Landman's aim is not to simply 'win an argument', but through narrative engagement to create awareness in both her coresearchers and in those reflecting on her research, of things that are out of place and things that need to be corrected.

Ultimately, as stated before, Landman's research concludes that society as a whole can only find healing once and when women find theirs. Thank you, Christina Landman, for these valuable lessons!

\section{Acknowledgements Competing interests}

The authors have declared that no competing interests exist.

\section{Authors' contributions}

W.B. and V.M.S.M. equally contributed to this article.

\section{Ethical consideration}

This article followed all ethical standards for carrying out research without direct contact with human or animal subjects.

\section{Funding information}

This research received no specific grant from any funding agency in the public, commercial or not-for-profit sectors. 


\section{Data availability statement}

Data sharing is not applicable to this article as no new data were created or analysed in this study.

\section{Disclaimer}

The scholarship offered in this article is original research offered by Prof. W. Bentley and Prof. V.M.S. Molobi, and the views are their own and not that of UNISA or any other party.

\section{References}

Baron, R.A., Byrne, D.R. \& Branscombe, N.R. (eds.), 2005, Social psychology, Allyn \& Bacon, Boston, MA.

Bentley, W., 2017, 'Schema-adjustment and Holy Communion: A transdisciplinary approach', In die Skriflig 51(1), 1-7. https://doi.org/10.4102/ids.v51i1.2311

Boesak, A., 2005, Die vlug van Gods verbeelding, SUN MeDIA, Stellenbosch.

Clandinin, D.J. (ed.), 2007, Handbook of Narrative Inquiry: Mapping a methodology, Sage, New Delhi.

Kelly, K., 2006, 'Lived experience and interpretation: The balancing act in qualitative research', in M. Terre Blanche, K. Durrheim \& D. Painter (eds.), Research in practice: Applied methods for the social sciences, pp. 345-369, UCT Press, Cape Town.

Landman, C., 1994, The piety of Afrikaans women: Diaries of guilt, Unisa Press, Pretoria.

Landman, C., 2009, 'Calvinism and South African women : A short historical overview', Studia Historiae Ecclesiasticae 35(2), 89-102.

Landman, C., 2012a, 'Lindiwe Myeza: Unfreezing the walking voice', Studia Historiae Ecclesiasticae 38(2), 1-8.
Landman, C., 2012b, 'Traumatised between culture and religion: Women's stories', HTS Theological Studies 68(2), 9-15. https://doi.org/10.4102/hts.v68i2.1147

Landman, C., 2013, 'Safe spaces for women in the church: The case of DullstroomEmnotweni', Studia Historiae Ecclesiasticae 39, 171-185.

Landman, C., 2014, 'The piety of German women in South Africa', Studia Historiae Ecclesiasticae 40(2), 119-129.

Landman, C., 2015, 'Youth on the margins as agents of change? The call for the opening of mines in Dullstroom-Emnotweni based on the Freedom Charter (1955)' Studia Historiae Ecclesiasticae 41(1), 156-168. https://doi.org/10.17159/2412 4265/2015/v41n1a11

Landman, C., 2017, 'Women flying with God: Allan Boesak's contribution to the liberation of women of faith in South Africa', Studia Historiae Ecclesiasticae 43(1), 1-12. http://doi.org/10.17159/2412-4265/2017/2720

Landman, C., 2019, 'Faces of religious healing in Nkhoma, Malawi: An exercise in oral history', Studia Historiae Ecclesiasticae 44(3), 1-17. https://doi.org/ $10.25159 / 24124265 / 5 n 5$

Landman, C. \& Yates, H., 2017, 'Africanity and research: A case study in rural South Africa', HTS Teologiese Studies/Theological Studies 73(4), 1-9. https://doi. org/10.4102/hts.v73i4.4775

Landman, C. \& Yates, H., 2018, "The church should teach us to do respect": Voices from rural youth in Mpumalanga, South Africa', HTS Teologiese Studies/ Theological Studies 74(3), 1-8.

Pinnegar, S. \& Daynes, J.G., 2007, 'Locating Narrative Inquiry historically: Thematics in the turn to narrative', in D.J. Clandinin (ed.), Handbook of narrative inquiry: Mapping a methodology, pp. 3-34, Sage, New Delhi.

Plaatjies Van Huffel, M.A., 2014, 'The remarkable career of Christina Landman, pioneer feminist theologian rooted in the reformed tradition', Studia Historiae Ecclesiasticae 40, 64-83.

Swartz, S., 2011, “"Going deep" and "giving back": Strategies for exceeding ethical expectations when researching amongst vulnerable youth', Qualitative Research 11(1), 47-68. https://doi.org/10.1177/1468794110385885

Tshaka, R.S., 2016, 'How can a conquered people sing praises of their history and culture? Africanization as the integration of inculturation and liberation', Black culture? Africanization as the integration of inculturation and liberation', Blac
Theology 14(2), 91-106. https://doi.org/10.1080/14769948.2016.1185841

Williams, D. \& Landman, C., 2016, 'The experiences of thirteen women ministers of the Methodist Church of Southern Africa', Studia Historiae Ecclesiasticae 42(1), 159-171. https://doi.org/10.17159/2412-4265/2016/1099 